\title{
Germinação de sementes de Aristolochia esperanzae O. Kuntze em diferentes temperaturas e condições de luminosidade
}

\author{
MAEKAWA, L. ${ }^{1}$; ALBUQUERQUE, M.C.F.* ; COELHO, M.F.B. ${ }^{2}$ \\ ${ }_{1}^{1}$ Programa de Pós-graduação em Agricultura Tropical, Faculdade de Agronomia e Medicina Veterinária (FAMEV)/ \\ Universidade Federal de Mato Grosso (UFMT), Av. Fernando Correia s/n, Coxipó, CEP: 78060-900, Cuiabá-Brasil \\ *mariacfa@terra.com.br ${ }^{2}$ Departamento de Ciências Vegetais, Universidade Federal Rural do Semi-Árido, Km 47 \\ da BR 110, Bairro Pres. Costa e Silva, CEP: 59625-900, Mossoró-Brasil coelhomfstrela@gmail.com
}

\begin{abstract}
RESUMO: O objetivo deste estudo foi verificar a influência da temperatura e da luz, em interação com a temperatura e de forma isolada, bem como, determinar a temperatura mais adequada para a condução do teste de germinação de sementes de Aristolochia esperanzae O. Kuntze (cipó mil-homens). Foram realizados três ensaios. No primeiro, as temperaturas utilizadas foram 15 , $20,25,30,35$ e $40^{\circ} \mathrm{C}$. No segundo, foi avaliada a germinação das sementes nas temperaturas de 25,30 e $35^{\circ} \mathrm{C}$, na presença e ausência de luz e no terceiro ensaio, foram testadas quatro condições de luminosidade, de forma isolada: (a) luz branca; (b) luz vermelha; (c) vermelho-distante e (d) ausência de luz, na temperatura de $25^{\circ} \mathrm{C}$. Em ambos os ensaios, foram avaliados, durante 30 dias, as porcentagens de sementes germinadas, de plântulas normais e de sementes não germinadas, e os tempos médios de sementes germinadas e de plântulas normais. Nas temperaturas de $15^{\circ} \mathrm{C}$ e de $40^{\circ} \mathrm{C}$, não ocorreram germinação de sementes de $A$. esperanzae. $\mathrm{O}$ melhor resultado para sementes germinadas e para formação de plântulas normais (96\%) foi obtido na temperatura de $30^{\circ} \mathrm{C}$. A presença de luz e as temperaturas de $25^{\circ} \mathrm{C}$ e $30^{\circ} \mathrm{C}$ favoreceram a germinação de sementes e a formação de plântulas normais. As sementes de Aristolochia esperanzae tiveram sua germinação inibida na ausência de luz, caracterizando-as como fotoblásticas positivas.
\end{abstract}

Palavras-chave: Aristolochiaceae, viabilidade, germinação, plantas medicinais

\begin{abstract}
Germination of Aristolochia esperanzae O. Kuntze seeds under different temperatures and light conditions. The aim of this study was to verify the influence of temperature and light, interacting or separately, as well as to establish the most suitable temperature to conduct the germination test of Aristolochia esperanzae O. Kuntze ("cipó mil-homens") seeds. Three assays were performed. In the first one, temperatures were $15,20,25,30,35$ and $40^{\circ} \mathrm{C}$. In the second assay, seed germination was evaluated at 25,30 and $35^{\circ} \mathrm{C}$, in the presence and absence of light. In the third assay, four light conditions were tested separately: (a) white light; (b) red light; (c) far-red light; and (d) no light, at $25^{\circ} \mathrm{C}$. In all assays, the percentages of germinated seeds, normal seedlings and non-germinated seeds, besides the mean times of germinated seeds and normal seedlings, were evaluated during 30 days. At $15^{\circ} \mathrm{C}$ and $40^{\circ} \mathrm{C}$, there was no $A$. esperanzae seed germination. The best result for germinated seeds and normal seedlings (96\%) was obtained at $30^{\circ} \mathrm{C}$. The presence of light and the temperatures $25^{\circ} \mathrm{C}$ and $30^{\circ} \mathrm{C}$ favored seed germination and normal seedling formation. Aristolochia esperanzae seeds had their germination inhibited in the absence of light, which characterizes them as positive photoblastic.
\end{abstract}

Key words: Aristolochiaceae, viability, germination, medicinal plants

\section{INTRODUÇÃO}

O processo de germinação é um evento fisiológico que depende da qualidade da semente e das condições de germinação, como o suprimento de água e oxigênio, adequação de temperatura, luz e substrato. A resposta das sementes a esses fatores varia com a espécie (Mayer \& Poljakoff-Mayber, 1982;

Recebido para publicação em 24/10/2008

Aceito para publicação em 21/09/2009

Rev. Bras. PI. Med., Botucatu, v.12, n.1, p.23-30, 2010. 
Borges \& Rena, 1993).

Esse processo só ocorrerá dentro de determinados limites de temperatura. A determinação exata das temperaturas cardeais (mínima, ótima e máxima) das várias espécies de interesse é dificultada por uma série de problemas, dentre os quais se destacam o nível de vigor das sementes e a definição de metodologia adequada (Carvalho \& Nakagawa, 2000).

A temperatura afeta a germinação de três maneiras distintas e isto pode ser registrado sobre o total, a velocidade e a uniformidade de germinação (Carvalho \& Nakagawa, 2000). É fator determinante para a germinação, associada às características da espécie, e pode agir como indutor de germinação para as espécies que apresentam dormência (Albuquerque et al., 2003).

Jesus \& Piña-Rodrigues (1991) citaram que a germinação de sementes, em relação à luz, é resposta ecofisiológica da espécie, e tem estreita correspondência com o posicionamento no estádio sucessional da floresta. Em sementes de espécies do cerrado, Felippe \& Silva (1984) citaram que a resposta à luz depende da temperatura nas quais as sementes foram expostas.

Além da variação da sensibilidade das sementes à luz entre espécies, também podem ocorrer variações numa única planta (Klein \& Felippe, 1991). A presença ou ausência de luz, combinada a diferentes temperaturas, são fatores ambientais dos mais comuns como agentes desencadeadores da germinação. Esses fatores em conjunto com a água, especialmente nos microsítios do solo, regulam a germinação (Bai et al., 1995).

Quando o comportamento germinativo das sementes é melhor na ausência do que na presença de luz, é designado de "fotoblastismo negativo" (Laboriau, 1983). O fotoblastismo é "absoluto", quando a germinação é nula na ausência de luz; o caráter "fotoblastismo positivo" segundo Klein \& Felippe (1991), nem sempre é absoluto, isto é, grande parte das espécies que, em laboratório, comportou-se como fotoblásticas positivas, apresentou pelo menos, alguma germinação no escuro. Esse é o comportamento encontrado por esses autores na germinação das espécies como Bidens pilosa L., Xantrium strumarium L., Euphorbia heterophylla L., Euterpe pilulifera L., Digitaria horizontalis Wild e Setaria geniculata (Lam.) P. Beauv.. As espécies nas quais o fotoblastismo positivo foi absoluto foram Euphorbia brasiliensis Lam., Phyllanthus corcovadensis Müll. Arg. e Portulaca oleraceae L.

As sementes da maioria das espécies são protegidas, durante o desenvolvimento, por estruturas clorofiladas. As diferentes respostas à luz, no processo de germinação, seriam impostas por diferenças na capacidade de filtrar a luz solar, apresentada pelos tecidos que protegem a semente em desenvolvimento. Ao amadurecer, a semente teria o fitocromo aprisionado num estado fotoestacionário, determinado pela quantidade da luz recebida imediatamente antes de secar. Assim, as sementes que amadurecem no interior de tecidos verdes teriam a maior parte do fitocromo na forma inativa (Fv), necessitando do estímulo luminoso para a germinação (Cresswell \& Grime, 1981).

Um dos fatores que influenciam a variação da resposta à luz durante a germinação é o período de pós-colheita das sementes (Klein \& Felippe, 1991). Sementes récem-colhidas de Portulaca oleraceae L. apresentaram comportamento fotoblástico positivo na germinação; no entanto, esse fotoblastimo não se manifestou durante o armazenamento (Lima \& Felippe, 1986).

As espécies medicinais de cerrado, normalmente, são indiferentes à luz e germinam tanto na presença como na ausência de luz (Albuquerque et al., 2003), mas segundo Salomão \& Sousa-Silva (2003), para algumas espécies, a luz estimula a germinação da semente ou diásporo.

Portanto, este estudo teve como objetivo verificar a influência da temperatura e da luz, em interação com a temperatura e de forma isolada, bem como, determinar a temperatura mais adequada para a condução do teste de germinação de sementes de Aristolochia esperanzae O. Kuntze (cipó mil-homens).

\section{MATERIAL E MÉTODO}

As sementes de Aristolochia esperanzae Kuntze (cipó mil-homens) foram coletadas de duas plantas, no Viveiro da Faculdade de Agronomia e Medicina Veterinária (FAMEV) e na Fazenda Experimental da Universidade Federal de Mato Grosso (UFMT), no período de julho a setembro de 2006. As sementes foram retiradas das inflorescências, limpas das impurezas com uso de peneiras, homogeneizadas e uniformizadas manualmente quanto ao tamanho. As sementes encontravam-se com teor de água de $9,8 \%$, não apresentando necessidade de secagem. Até o momento de realização de cada experimento (novembro de 2006), as sementes foram colocadas em caixas de plástico, envolvidas em sacola de plástico transparente e armazenadas em ambiente a $15^{\circ} \mathrm{C} \pm 2^{\circ} \mathrm{C}$ e $80 \% \pm 4 \%$ UR.

Foram realizados três ensaios. No primeiro ensaio foram utilizadas as temperaturas constantes de $15,20,25,30,35$ e $40^{\circ} \mathrm{C}$, em câmaras de germinação reguladas em fotoperíodo de 8 horas. $O$ delineamento foi inteiramente casualizado com seis tratamentos e quatro repetições. As sementes foram colocadas para germinar em substrato de papel toalha na forma de rolo, umedecido com água destilada na quantidade de 2,5 vezes a massa do papel seco, em 
quatro subamostras de 50 sementes. Os substratos foram mantidos dentro de sacolas de plástico transparente para manutenção da umidade e, aproximadamente a cada três dias, foi feito o reumedecimento do papel com água destilada. As sementes que não germinaram, durante 30 dias, nas temperaturas de $15,20,35$ e $40^{\circ} \mathrm{C}$, foram colocadas em câmara de germinação reguladas a $25^{\circ} \mathrm{C}$ por mais trinta dias.

No segundo ensaio foi avaliada a germinação de $A$. esperanzae em ausência e presença de luz, nas temperaturas de 25,30 e $35^{\circ} \mathrm{C}$ em quatro subamostras de 25 sementes cada. As sementes foram colocadas sobre papel mata borrão em caixas de plástico transparente, medindo $11,0 \times 11,0 \times 3,5$ $\mathrm{cm}$. Para o estudo da ausência de luz, as sementes foram colocadas em caixas de plástico preto com as mesmas dimensões. $O$ substrato foi umedecido com água destilada até a saturação e retirado o excesso. Na temperatura de $25^{\circ} \mathrm{C}$, o reumedecimento foi feito uma vez por semana e, devido ao maior dessecamento, nas temperaturas de 30 e $35^{\circ} \mathrm{C}$, esse reumedecimento foi realizado duas vezes por semana. Foi utilizado o delineamento experimental inteiramente casualizado em esquema fatorial $3 \times 2$, sendo três temperaturas, duas condições de luminosidade e quatro repetições.

No terceiro ensaio foi avaliada a germinação de sementes de $A$. esperanzae submetidas às seguintes condições de luz: luz vermelha, luz vermelho-distante, luz branca e ausência de luz, em câmara de germinação regulada a $25^{\circ} \mathrm{C}$ e fotoperíodo de oito horas. O delineamento foi inteiramente casualizado com quatro tratamentos e cinco repetições de 25 sementes cada. $\mathrm{Na}$ simulação da luz vermelha e vermelha-distante foi usada a metodologia citada por Cardoso (1995). A luz vermelha foi obtida através de filtro constituído por duas folhas de papel celofane vermelho recortado e colado no lado externo da caixa de plástico transparente. Para a luz vermelha extrema foram usadas duas folhas de papel celofane vermelho e duas folhas de papel celofane azul marinho, coladas na parte externa da caixa de plástico. As sementes do tratamento luz branca foram colocadas em caixas de plástico transparente e as do tratamento ausência de luz, em caixas de plástico preto. O substrato utilizado foi o papel mata borrão saturado com água destilada, retirando-se o excesso. O reumedecimento foi realizado semanalmente.

As sementes que não germinaram durante o período de 30 dias, nos tratamentos ausência de luz e vermelha distante, foram colocadas em caixas de plástico transparente por mais 20 dias na temperatura de $25^{\circ} \mathrm{C}$, com fotoperíodo de 8 horas, e avaliada a formação de plântulas normais.

Em todos os ensaios, as avaliações foram realizadas durante 30 dias, e foram consideradas germinadas as sementes que emitiram raízes com 2 $\mathrm{mm}$ de comprimento. Foi verificada também a formação de plântulas normais segundo critérios de Brasil (1992) e foram calculadas as porcentagens e os tempos médios de sementes germinadas (germinação) e de plântulas normais (Laboriau, 1983). No ensaio de temperatura foram avaliadas também as sementes não germinadas (sementes mortas e sementes firmes). Foram consideradas como sementes firmes aquelas que absorveram água e não deterioraram.

As caixas de plástico foram envolvidas com filme plástico de policloreto de vinila (PVC) transparente, para evitar a perda de água. A avaliação no tratamento ausência de luz, e nos tratamentos com luz vermelha e vermelha distante foi realizada em ambiente escuro e com uso de lanterna com filtro de segurança formado por três folhas de papel celofane verde, obtendo a luz na faixa verde, tida como luz de segurança (Cardoso, 1995).

Nos três ensaios, para a análise de variância foi usado o teste F. Quando necessário, os dados foram transformados para atenderem os pressupostos de normalidade e homogeneidade. Para tanto, os dados de tempos médios de sementes germinadas e de plântulas normais, do segundo ensaio, foram transformados em $\sqrt{(x+0,5)}$. No terceiro ensaio, os dados de tempo médio de sementes germinadas foram transformados para log $(x+1)$ e os de tempo médio de formação de plântulas normais para $\sqrt{(x+1)}$. As médias foram comparadas pelo teste Tukey a $5 \%$ de probabilidade. $\mathrm{Na}$ análise dos dados utilizou-se o programa estatístico SAEG, versão 5.0.

\section{RESULTADOE DISCUSSÃO}

\section{Efeito de temperaturas constantes}

A temperatura influenciou de forma significativa no processo germinativo de sementes de $A$. esperanzae, observando-se que não ocorreu germinação nas temperaturas de 15 e $40^{\circ} \mathrm{C}$ (Tabela 1).

Ocorreu aumento gradual na protrusão de raiz e na formação de plântulas normais a partir de $20^{\circ} \mathrm{C}$, $45 \%$ e $21 \%$ respectivamente, até a temperatura de $30^{\circ} \mathrm{C}(96 \%)$ (Tabela 1). A 35드 ocorreu decréscimo nas porcentagens de sementes germinadas e de plântulas normais. As sementes que não germinaram na temperatura de $20^{\circ} \mathrm{C}$, quando colocadas a $25^{\circ} \mathrm{C}$ por mais 30 dias, formaram $47 \%$ de sementes germinadas, totalizando $92 \%$ de germinação final.

$\mathrm{Na}$ temperatura de $25^{\circ} \mathrm{C}$, as porcentagens de sementes germinadas e de plântulas normais foram respectivamente $91 \%$ e $89 \%$. No tratamento com $30^{\circ} \mathrm{C}$, todas as sementes que emitiram raízes formaram plântulas normais e a $35^{\circ} \mathrm{C}$ somente $15 \%$ das sementes que formaram raízes desenvolveram- 
se em plântulas normais. Nessa temperatura ocorreu dessecamento de parte das raízes emitidas.

As temperaturas de 25 e $30^{\circ} \mathrm{C}$ foram mais favoráveis para a germinação de sementes de $A$. esperanzae (Tabela 1), com 91 e 96\%, respectivamente; mas, quando foram observadas a porcentagem e o tempo médio para formação de plântulas normais, foi verificado que a temperatura de $30^{\circ} \mathrm{C}$ foi mais adequada para a condução do teste de germinação (96\% de plântulas normais no tempo médio de 17,89 dias), porcentagem superior à observada nas demais temperaturas e em menor período de tempo.

Carvalho \& Nakagawa (2000) citaram que a temperatura ótima para porcentagem de germinação é diferente da ótima para velocidade de germinação, sendo mais elevada para essa última; entretanto, pode ser observado na Tabela 1 que, tanto para as porcentagens como para os tempos médios de sementes germinadas e de formação de plântulas normais, a temperatura ótima foi a mesma.

Os resultados encontrados reforçam a afirmação de Salomão \& Souza-Silva (2003), de que as sementes de espécies de cerrado respondem, favoravelmente, à temperatura de incubação de $25^{\circ} \mathrm{C}$, embora a temperatura ótima de germinação, para algumas sementes ou diásporos, seja de $30^{\circ} \mathrm{C}$.

O tempo médio de sementes germinadas, na temperatura de $20^{\circ} \mathrm{C}$, foi o maior entre os tratamentos e diferiu, estatisticamente, das temperaturas de 25, 30 e 35으. Embora a germinação (sementes germinadas) na temperatura de $20^{\circ} \mathrm{C}$, tenha sido menor que a germinação na temperatura

TABELA 1. Resultados médios de sementes germinadas ( $S G$ ) e de plântulas normais (PN), tempos médios de germinação e de formação de plântulas normais (TMSG e TMPN), de sementes mortas (SM) e de sementes firmes (SF) de Aristolochia esperanzae em diferentes temperaturas.

\begin{tabular}{ccccccc}
\hline $\begin{array}{c}\text { Temperaturas } \\
\left({ }^{\circ} \mathbf{C}\right)\end{array}$ & $\begin{array}{c}\text { SG } \\
\%\end{array}$ & $\begin{array}{c}\text { TMSG } \\
\text { (dias) }\end{array}$ & $\begin{array}{c}\text { PN } \\
\%\end{array}$ & $\begin{array}{c}\text { TMPN } \\
\text { (dias) }\end{array}$ & SM\% & $\begin{array}{c}\text { SF } \\
\%\end{array}$ \\
\hline 15 & - & - & - & - & 12 & 88 \\
20 & $45 \mathrm{C}$ & $22,2 \mathrm{~A}$ & $21 \mathrm{C}$ & $28,6 \mathrm{~A}$ & 8 & 47 \\
25 & $91 \mathrm{~A}$ & $16,1 \mathrm{~B}$ & $89 \mathrm{~B}$ & $21,5 \mathrm{C}$ & 6 & 3 \\
30 & $96 \mathrm{~A}$ & $13,3 \mathrm{~B}$ & $96 \mathrm{~A}$ & $17,9 \mathrm{D}$ & 4 & 0 \\
35 & $70 \mathrm{~B}$ & $16,1 \mathrm{~B}$ & $15 \mathrm{D}$ & $25,1 \mathrm{~B}$ & 30 & 0 \\
40 & - & - & - & - & 100 & 0 \\
\hline $\mathbf{C V}(\%)$ & 8,11 & 9,45 & 6,56 & 5,03 & &
\end{tabular}

Médias seguidas da mesma letra maiúscula na coluna, não diferem entre si pelo teste Tukey a $5 \%$ de probabilidade.

de $35^{\circ} \mathrm{C}$, a formação de plântulas, ao final do experimento, foi maior na temperatura de $20^{\circ} \mathrm{C}$ (Tabela 1). Houve maior efeito da temperatura na formação de plântulas do que na germinação, com variação também no tempo médio de plântulas normais que variou em todas as temperaturas. As temperaturas abaixo de $25^{\circ} \mathrm{C}$ e acima de $30^{\circ} \mathrm{C}$ causaram danos na germinação de sementes de $A$. esperanzae.

$\mathrm{Na}$ temperatura de $15^{\circ} \mathrm{C}$ não ocorreu germinação, mas a mesma não causou a morte das sementes, o que foi verificado na temperatura de $40^{\circ} \mathrm{C}$. As sementes firmes oriundas da temperatura de $15^{\circ} \mathrm{C}$, quando colocadas a $25^{\circ} \mathrm{C}$ por mais 30 dias, apresentaram $88 \%$ de sementes germinadas. A redução gradativa da temperatura, em função dos efeitos sobre a velocidade de embebição e de mobilização de reservas, provoca decréscimo acentuado da velocidade de germinação (Marcos Filho, 2005).

$O$ efeito negativo das temperaturas altas sobre o processo germinativo tem sido atribuído à diminuição do suprimento de aminoácidos livres, da síntese de RNA e de proteínas, além do decréscimo das reações metabólicas, o que pode retardar ou suprimir a germinação, ou até mesmo causar a perda da viabilidade das sementes (Riley, 1981, citado por Andrade et al., 1999).

Scalon et al. (2007) verificaram que sementes de $A$. triangulares Cham. Et Schl. não germinaram a $18^{\circ} \mathrm{C}$, o que indica a sensibilidade de sementes do gênero Aristolochia a temperaturas mais baixas do que $20^{\circ} \mathrm{C}$. Esses autores citaram que cada espécie apresenta diferenças marcantes quanto à germinação em diferentes temperaturas.

Da mesma forma como observado com sementes de $A$. esperanzae, na temperatura de $40^{\circ} \mathrm{C}$ não ocorreu germinação de sementes de três espécies do gênero Syngonanthus (Eriocaulaceae) (Oliveira \& Garcia, 2005) e de sementes de aroeira (Myracrodruon urundeuvaAllemão) (Silva et al., 2002).

Foi observado na temperatura de $20^{\circ} \mathrm{C}$, plântulas com menor tamanho do que a 25 e $30^{\circ} \mathrm{C}$. Nessas duas temperaturas as plântulas apresentaram maior desenvolvimento e ficaram mais 
esverdeadas; a 35ํㅡ poucas plântulas normais foram formadas e a temperatura mais elevada ocasionou necrose na ponta das raízes das sementes.

Na temperatura de $20^{\circ} \mathrm{C}$, o início da germinação ocorreu no $14^{\circ}$ dia após a semeadura; nas temperaturas de 25,30 e $35^{\circ} \mathrm{C}$, as raízes foram emitidas, respectivamente, nos 11, 10 e 10 dias, após a semeadura. Somente a $30^{\circ} \mathrm{C}$, todas as sementes viáveis haviam germinado no 26 dia após o início do experimento.

Considerando que a temperatura ótima é aquela onde ocorre a maior porcentagem de germinação no menor período de tempo, a máxima e a mínima, quando a germinação é zero (Borges \& Rena, 1993), pode-se afirmar que, para sementes de A. esperanzae, a temperatura ótima foi de $30^{\circ} \mathrm{C}$; a mínima situou-se entre 15 e $20^{\circ} \mathrm{C}$ e a máxima, entre 35 e $40^{\circ} \mathrm{C}$. A germinabilidade ocorreu em uma faixa de temperatura compreendida entre 20 e $35^{\circ} \mathrm{C}$.

Essa faixa de germinabilidade foi similar à de várias espécies como manduirana, Senna macranthera (Collad.) Irwin et Barn. (Silva, 2001), cuja faixa ótima situou-se entre 27 e $30^{\circ} \mathrm{C}$; cerejeira, Torresia acreana Ducke (Bello, 2005) e nó-decachorro, Heteropteris aphrodisiaca O. Mach. (Arruda, 2001), cuja temperatura mais adequada para germinação foi de $30^{\circ} \mathrm{C}$. Também, para sementes de bertalha, Basella rubra L. (Lopes et al., 2005) e de pau balsa, Ochroma pyramidale (Cav. ex Lam.) Urb. (Ramos et al., 2006), a temperatura de $30^{\circ} \mathrm{C}$ foi a mais adequada para o processo germinativo.

\section{Efeito da interação luz e temperatura}

Foi verificado efeito da interação entre temperatura e luz para sementes germinadas e formação de plântulas de $A$. esperanzae, para o tempo médio de sementes germinadas ocorreu efeito da temperatura e para o tempo médio de formação de plântulas, efeito da luz.

$\mathrm{Na}$ Tabela 2, encontram-se os resultados de porcentagens de sementes germinadas (germinação) e de formação de plântulas normais onde foi observado claramente o efeito significativo da luminosidade. $\mathrm{Na}$ presença de luz, a germinação nas três temperaturas foi significativamente superior à germinação na ausência de luz. Nas temperaturas de 25 e $30^{\circ} \mathrm{C}$, na presença de luz, a germinação foi de 97 e 99\%, respectivamente, enquanto que na ausência de luz foi de 7 e 3\%, respectivamente. Os resultados apresentados nessas duas temperaturas diferiram dos encontrados na temperatura de $35^{\circ} \mathrm{C}$, onde foi verificado decréscimo na germinação de sementes na presença de luz. Na ausência de luz a germinação de sementes foi maior na temperatura de $35^{\circ} \mathrm{C}$.

Para a formação de plântulas normais também foi verificado efeito da luz (Tabela 2) e na ausência da luz não foi observada nenhuma plântula a $35^{\circ} \mathrm{C}$. Nas temperaturas de 25 e $30^{\circ} \mathrm{C}$ ocorreram as maiores porcentagens de formação de plântulas, 97 e $91 \%$ respectivamente.

Todas as sementes que emitiram raízes (germinação) a $25^{\circ} \mathrm{C}$ na presença de luz, formaram plântulas (Tabela 2). Na temperatura de $30^{\circ} \mathrm{C}$, embora $99 \%$ das sementes tenham emitido raízes, somente $91 \%$ formaram plântulas completas. Na temperatura de $35^{\circ} \mathrm{C}$, na presença de luz, a formação de plântulas foi menor (31\%), embora a germinação tenha atingido $73 \%$. Nessa temperatura, $42 \%$ das sementes que emitiram raízes não conseguiram formar plântulas pela desidratação causada pelo excesso de calor. $\mathrm{Na}$ ausência de luz, a $35^{\circ} \mathrm{C}$, embora $18 \%$ tenham emitido raízes, nenhuma semente conseguiu formar plântulas (Tabela 2).

O tempo médio de sementes germinadas não apresentou efeito da condição de luminosidade, somente da temperatura (Tabela 3). Já no tempo médio de formação de plântulas foi observado o efeito da luz, pois a $35^{\circ} \mathrm{C}$, na ausência de luz, não ocorreu formação de plântulas (Tabelas 2 e 3). O tempo médio de sementes germinadas variou de 6,3 dias a $30^{\circ} \mathrm{C}$ para 20,1 dias a $35^{\circ} \mathrm{C}$, ambos na ausência de luz. $\mathrm{O}$ tempo médio de formação de plântulas variou de 12 a 22,1 dias.

$\mathrm{Na}$ ausência de luz, os resultados de germinação e plântulas normais foram menores,

TABELA 2. Resultados médios (\%) de germinação e de plântulas normais de $A$. esperanzae em diferentes temperaturas e condições de luz.

\begin{tabular}{llrrr}
\hline \multirow{2}{*}{ Variável } & Luz & \multicolumn{3}{c}{ Temperatura (ํㅜ) } \\
\cline { 3 - 5 } & & \multicolumn{1}{c}{$\mathbf{2 5}$} & \multicolumn{1}{c}{$\mathbf{3 0}$} & \multicolumn{1}{c}{$\mathbf{3 5}$} \\
\hline Germinação & Ausência & $7 \mathrm{Bb}$ & $3 \mathrm{Bb}$ & $18 \mathrm{Ba}$ \\
& Presença & $97 \mathrm{Aa}$ & $99 \mathrm{Aa}$ & $73 \mathrm{Ab}$ \\
\hline Plântulas Normais & Ausência & $4 \mathrm{Ba}$ & $2 \mathrm{Ba}$ & $0 \mathrm{Ba}$ \\
& Presença & $97 \mathrm{Aa}$ & $91 \mathrm{Aa}$ & $31 \mathrm{Ab}$ \\
\hline
\end{tabular}

Médias seguidas da mesma letra maiúscula na coluna e minúscula na linha, na mesma variável, não diferem entre si pelo teste Tukey a $5 \%$ de probabilidade. 
significativamente, que os obtidos na presença de luz, o que pode caracterizar $A$. esperanzae como espécie fotoblástica positiva, embora não seja absoluto, pois houve germinação e formação de plântulas na ausência de luz nas temperaturas de 25 e 30ㄷ (Tabela 2). Klein \& Fellipe (1991) comentaram que o fotoblastismo positivo nem sempre é absoluto, pois no laboratório, em grande parte das espécies, sempre ocorre alguma germinação no escuro. Na temperatura de $35^{\circ} \mathrm{C}$ o fotoblastismo foi absoluto, mas provavelmente esse efeito foi mais da temperatura que da ausência de luz.

Conforme Ferreira et al. (2001), para serem fotoblásticas positivas, a germinação das sementes deve atingir mais do que o dobro do regime do escuro, o que de fato aconteceu com as sementes de $A$. esperanzae (Tabela 2).

Os resultados encontrados com sementes de $A$. esperanzae diferem dos verificados com a espécie $A$. triangulares onde Scalon et al. (2007) caracterizaram as sementes como neutras. Entretanto, esses autores utilizaram condições experimentais diferentes e temperatura alternada (20$30^{\circ} \mathrm{C}$ ). A sensibilidade luminosa pode ser alterada em função da temperatura (Smitth, 1975; Silva et al., 2005) e algumas espécies apresentam maior germinação a 20 e $25^{\circ} \mathrm{C}$ na presença de luz, entretanto, a germinação pode não ocorrer ou ser reduzida quando submetidas a 15, 20, 25 e 30ㄷ na ausência de luz (Silva et al., 2005). Também Araújo Neto et al. (2005) citaram que a resposta à luz pode ser influenciada por vários fatores, entre eles o ambiente de germinação e que em temperaturas abaixo da ótima, algumas espécies não fotoblásticas passam a exigir luz para iniciar o processo de germinação. Entretanto, as temperaturas usadas neste experimento com $A$. esperanzae tenham sido determinadas previamente e caracterizadas como adequadas para a germinação.

Garcia et al. (2006) estudaram o comportamento germinativo de duas espécies de canga ferrífera: Baccharis retusa DC. (Asteraceae) e Tibouchina multiflora Cogn. (Melastomataceae) e também verificaram que essas duas espécies apresentam comportamento fotoblástico positivo, com germinação inexpressiva no escuro, em todas as temperaturas testadas $\left(15,20,25\right.$ e $\left.30^{\circ} \mathrm{C}\right)$.

\section{Efeito de diferentes condições de luminosidade}

$\mathrm{Na}$ Tabela 4 encontram-se os resultados de germinação de $A$. esperanzae, em diferentes condições de luminosidade. Pode-se verificar o efeito significativo das diferentes condições de luminosidade

TABELA3. Resultados de tempos médios (dias) de germinação e de formação de plântulas normais de $A$. esperanzae em diferentes temperaturas e condições de luz.

\begin{tabular}{llccc}
\hline \multicolumn{1}{c}{ Variável } & Luz & \multicolumn{3}{c}{ Temperatura (ㅇ) } \\
\cline { 3 - 5 } & & $\mathbf{2 5}$ & $\mathbf{3 0}$ & $\mathbf{3 5}$ \\
\hline Germinação & Ausência & $18,9 \mathrm{Aa}$ & $6,3 \mathrm{Ab}$ & $20,1 \mathrm{Aa}$ \\
& Presença & $17,5 \mathrm{Aa}$ & $11,6 \mathrm{Aa}$ & $14,9 \mathrm{Aa}$ \\
\hline \multirow{2}{*}{ Plântulas Normais } & Ausência & $14,8 \mathrm{Aa}$ & $12,0 \mathrm{Aa}$ & $0 \mathrm{Ba}$ \\
& Presença & $22,1 \mathrm{Aa}$ & $14,5 \mathrm{Aa}$ & $17,3 \mathrm{Aa}$ \\
\hline
\end{tabular}

Médias seguidas da mesma letra maiúscula na coluna e minúscula na linha, na mesma variável, não diferem entre si pelo teste Tukey a $5 \%$ de probabilidade. Médias originais.

TABELA 4. Porcentagens de sementes germinadas (SG) e formação de plântulas (PN) e respectivos tempos médios de sementes germinadas (TMSG) e de formação de plântulas (TMPN) de $A$. esperanzae sob diferentes condições de luminosidade.

\begin{tabular}{lrrrr}
\hline $\begin{array}{c}\text { Condições de } \\
\text { Luminosidade }\end{array}$ & $\begin{array}{c}\text { G } \\
\text { (\%) }\end{array}$ & $\begin{array}{c}\text { PN } \\
\text { (\%) }\end{array}$ & $\begin{array}{c}\text { TMG } \\
\text { (dias) }\end{array}$ & \multicolumn{1}{c}{$\begin{array}{c}\text { TMP } \\
\text { (dias) }\end{array}$} \\
\hline Luz branca & $79 \mathrm{~A}$ & $75 \mathrm{~A}$ & $20,4 \mathrm{~A}$ & $24,3 \mathrm{~A}$ \\
Luz vermelha & $83 \mathrm{~A}$ & $81 \mathrm{~A}$ & $19,5 \mathrm{~A}$ & $23,4 \mathrm{~A}$ \\
Vermelho-distante & $8 \mathrm{~B}$ & $3 \mathrm{~B}$ & $11,6 \mathrm{AB}$ & $11,7 \mathrm{AB}$ \\
Ausência de luz & $1,6 \mathrm{~B}$ & $0 \mathrm{~B}$ & $6,0 \mathrm{~B}$ & $0 \mathrm{~B}$ \\
\hline
\end{tabular}

Médias seguidas da mesma letra maiúscula na coluna, não diferem entre si pelo teste Tukey a $5 \%$ de probabilidade. Médias originais. 
nas porcentagens e nos tempos médios de sementes germinadas e de formação de plântulas normais. As sementes de $A$. esperanzae apresentaram alta porcentagem de germinação nas condições de luz branca e luz vermelha. Borges \& Rena (1993) citaram que a luz branca, devido composição espectral e características do fitocromo, têm efeito semelhante ao da luz vermelha.

Verificou-se novamente que a germinação foi mínima e que não houve formação de plântulas na ausência de luz, o que caracteriza a espécie $A$. esperanzae como espécie fotoblástica positiva. De acordo com Cresswell \& Grime (1981), as sementes que amadurecem no interior de tecidos verdes teriam, em tese, a maior parte do fitocromo na forma inativa (Fv), necessitando, portanto, do estímulo luminoso para a germinação. As sementes de $A$. esperanzae desenvolvem-se em estrutura de coloração verde e, talvez por isso, tenham necessitado do estímulo luminoso para germinar.

As sementes de espécies pioneiras fotoblásticas respondem com germinação plena apenas quando são submetidas à luz vermelha, enquanto as pertencentes aos demais grupos ecológicos, como as secundárias e as clímax, têm a capacidade de germinar à sombra do dossel, sem luz solar direta (Kageyama \& Viana, 1991).

Araújo et al. (2002) observaram, em testes de germinação conduzidos a $30^{\circ} \mathrm{C}$, em sementes recém-colhidas de mutamba (Guazuma ulmifolia Lam.), que as mesmas tiveram a germinação promovida pelas luzes branca e vermelha, mas inibida pela luz vermelho-distante e ausência de luz. As sementes armazenadas, entretanto, revelaram-se insensíveis à luz.

As sementes de $A$. esperanzae, utilizadas nos dois ensaios de luminosidade, foram analisadas em períodos diferentes. No primeiro ensaio, os testes de germinação foram realizados dois meses após a coleta das sementes e, no segundo ensaio, oito meses depois da coleta. Em ambos os ensaios, foi verificado o fotoblastismo positivo das sementes de A. esperanzae (Tabelas 2 e 4). As sementes germinaram bem, quando submetidas à luz branca e vermelha e quase não germinaram na ausência de luz ou sob luz vermelho-distante.

Valio \& Scarpa (2001) estudaram a germinação de sementes de oito espécies pioneiras tropicais (Cecropia hololeuca Miq., C. pachystachya Trécul, C. glazioui Snethlage, Solanum gracillimum Sendrn, S. granuloso-leprosum Dunal, S. tabacifolium Salzm. Ex Dunal, Croton floribundus Spreng e Miconia chamissois Naudin), sob condições controladas de temperatura e luminosidade. Com exceção de $C$. floribundus, todas as outras espécies se mostraram fotoblásticas positivas, sendo que altas porcentagens de germinação foram encontradas sob condições de luz. A germinação foi drasticamente reduzida sob baixas razões de vermelho:vermelho-distante. A baixa razão vermelho:vermelho-distante, prevalecente sob o dossel, parece ter sido o fator crucial que afetou a germinação.

As sementes que não germinaram nas condições de luz vermelho-distante e de ausência de luz foram colocadas para germinar sob luz branca a $25^{\circ} \mathrm{C}$ onde apresentaram germinação final de $84 \%$ e $83 \%$, respectivamente. Esses resultados evidenciaram que as condições de ausência de luz ou de luz vermelho-distante somente inibem a germinação e que logo que as condições de luminosidade sejam estabelecidas, ocorrerá a germinação das sementes.

\section{CONCLUSÃO}

A germinabilidade de sementes e formação de plântulas normais de $A$. esperanzae ocorrem na faixa de temperatura compreendida entre 20 e $35^{\circ} \mathrm{C}$.

A temperatura de $30^{\circ} \mathrm{C}$ é a mais adequada para a condução do teste de germinação de sementes de $A$. esperanzae, no substrato rolo de papel.

As sementes de $A$. esperanzae têm sua germinação inibida na ausência de luz, caracterizandoas como fotoblásticas positivas.

\section{REFERÊNCIA}

ALBUQUERQUE M.C.F.; COELHO, M.F.B.; ALBRECTH, J.M.F. Germinação de sementes de espécies medicinais do cerrado, In: COELHO, M.F.B.; COSTA JR., P.; DOMBROSKI, J.L.D. (Orgs.). Diversos olhares em etnobiologia, etnoecologia e plantas medicinais. Cuiabá: Unicen, 2003. p.157-82.

ANDRADE, A.C.S. et al. Reavaliação do efeito do substrato e da temperatura na germinação de sementes de palmiteiro (Euterpe edulis Mart.). Revista Árvore, v.23, n.3, p.279-83, 1999.

ARAÚJO NETO, J.C. et al. Temperaturas cardeais e efeitos da luz na germinação de sementes de mutamba. Revista Brasileira de Engenharia Agrícola e Ambiental, v.6, n.3, p.460-5, 2002.

ARAÚJO NETO, J.C. et al. Armazenamento e requerimento fotoblástico de sementes de Acacia polyphylla DC. Revista Brasileira de Sementes, v.27, n.1, p.115-24, 2005.

ARRUDA, J.B. Aspectos da germinação e cultivo do nó-de-cachorro (Heteropteris aphrodisiaca O. Mach). 2001. 142p. Dissertação (Mestrado em Agricultura Tropical)-Faculdade de Agronomia e Medicina Veterinária, UFMT, Cuiabá.

BAI, Y.; ROMO, J.T.; YOUNG, J.L. Influences of temperature, light and water stress on germination of fringed sage (Artemisia frigida). Weed Science, v.43, p.219-25, 1995.

BELLO, E.P.B.C.E.S. Influência de substratos, temperatura, estresse hídrico e armazenamento na germinação de Torresia acreana Ducke. 2005. 93p. 
Dissertação (Mestrado em Agricultura Tropical)Faculdade de Agronomia e Medicina Veterinária, UFMT, Cuiabá.

BORGES, E.E.L.; RENA, A.B. Germinação de sementes. In: AGUIAR, I.B.; PIÑA-RODRIGUES, F.C.M.; FIGLIOLIA, M.B. (Coord.). Sementes florestais tropicais. Brasília: ABRATES, 1993. p.137-74.

BRASIL. Regras para análise de sementes. Brasília: Ministério da Agricultura e Reforma Agrária, 1992. 365p. CARDOSO, V.J.M. Germinação e fotoblastismo de sementes de Cucumis anguria: influência da qualidade da luz durante a maturação e secagem. Revista Brasileira de Fisiologia Vegetal, v.7, n.1, p.75-80, 1995. CARVALHO, N.M.; NAKAGAWA, J. Sementes: ciência, tecnologia e produção. 4.ed. Jaboticabal: FUNEP, 2000. $588 p$.

CRESSWELL, E.G.; GRIME, J.P. Introduction of a light reguirement during seed development ands its ecological conseqüences. Nature, v.29, p.583-5, 1981. FELIPPE, G.M.; SILVA, J.C.S. Estudos de germinação em espécies do cerrado. Revista Brasileira de Botânica, v.7, n.2, p.157-63, 1984.

FERREIRA, A.G. et al. Germinação de sementes de Asteraceae nativas no Rio Grande do Sul, Brasil. Acta Botanica Brasilica, v.15, n.2, p.231-42, 2001.

GARCIA, L.C.; BARROS, F.V.; LEMOS FILHO, J.P. Comportamento germinativo de duas espécies de canga ferrífera: Baccharis retusa DC. (Asteraceae) e Tibouchina multiflora Cogn. (Melastomataceae). Acta Botanica Brasilica, v.20, n.2, p.443-8, 2006.

JESUS, R.M.; PIÑA-RODRIGUES, F.C.M. Programa de produção e tecnologia de sementes florestais de Floresta Rio Doce S.A.: uma discussão dos resultados obtidos. In: SIMPÓSIO BRASILEIRO SOBRE TECNOLOGIA DE SEMENTES FLORESTAIS, 2., 1989, Atibaia. Anais... São Paulo: Instituto Florestal, 1991. p.59-86.

KAGEYAMA, P.Y.; VIANA, V.M. Tecnologia de sementes e grupos ecológicos de espécies arbóreas tropicais. In: SIMPÓSIO BRASILEIRO SOBRE TECNOLOGIA DE SEMENTES FLORESTAIS, 2., 1989, Atibaia. Anais... São Paulo: Instituto Florestal, 1991. p.197-215.

KLEIN, A.; FELIPPE, G.M. Efeito da luz na germinação de sementes de ervas invasoras. Pesquisa Agropecuária Brasileira, v.26, n.7, p.955-66, 1991.

LABORIAU, L.G. A germinação das sementes. Washington D. C.: Secretaria Geral das Organizações dos Estados Americanos, Programa Regional de Desenvolvimento Científico e Tecnológico, 1983. 174p.
LIMA, R.F.; FELIPPE, G.M. Efeito da luz e temperatura na germinação de Portulaca oleracea. Ciência e Cultura, v.38, n.9, p.1577-89, 1986.

LOPES, J.C. et al. Influência de temperatura, substrato e luz na germinação de sementes de bertalha. Revista Brasileira de Sementes, v.27, n.2, p.18-24, 2005. MARCOS FILHO, J. Fisiologia de sementes de plantas cultivadas. Piracicaba: FEALQ, 2005. 425p.

MAYER, A.M.; POLJAKOFF-MAYBER, A. The germination of seeds. 3.ed. New York: Pergamon, 1982. 211p.

OLIVEIRA, P.G.; GARCIA, Q.S. Efeito da luz e da temperatura na germinação de sementes de Syngonanthus elegantulus Ruhland, S. elegans (Bong.) Ruhland e $S$. venustus Silveira (Eriocaulaceae). Acta Botanica Brasilica, v.19, n.3, p.639-45, 2005.

RAMOS, M.B.P.; VARELA, V.P.; MELO, M.F.F. Influência da temperatura e da quantidade de água no substrato sobre a germinação de sementes de Ochroma pyramidale (Cav. ex. Lam.) Urban (pau-balsa). Acta Amazonica, v.36, n.1, p.103-6, 2006.

SALOMÃO, A.N.; SOUSA-SILVA, J.C. Germinação, análise e armazenamento de sementes. In: SALOMẪO, A.N. et al. (Org.). Germinação de sementes e produção de mudas de plantas do Cerrado. Brasília: Rede de Sementes do Cerrado, 2003. 96p.

SCALON, S.P.Q. et al. Temperatura, luz e substrato na germinação de sementes de cipó-mil-homens (Aristolochia triangulares Cham. Et Schl.). Revista Brasileira de Plantas Medicinais, v.9, n.4, p.32-8, 2007. SILVA, L.M.M.; RODRIGUES, T.J.D.; AGUIAR, I.B. Efeitos da luz e da temperatura na germinação de sementes de aroeira (Myracrodruon urundeuva Allemão). Revista Árvore, v.26, n.6, p.691-7, 2002.

SILVA, M.C. Efeito da temperatura na germinação de sementes de manduirana (Senna macranthera (Collad.) Irwin et Barn. - Caesalpiniaceae). Revista Brasileira de Sementes, v.23, n.1, p.92-9, 2001.

SILVA, M.A.B. et al. Influência da luz e da temperatura na germinação de sementes de gerbera (Gerbera jamesonii Bolus ex Hook). Horticultura Brasileira, v.23, n.2, supl., 2005. 1CD ROM.

SMITH, H. Light quality and germination: ecological implications. In: HEYDECHER, W. Seed Ecology. London: Buttrworth, 1975. p.131-219.

VALIO, I.F.M.; SCARPA, F.M. Germination of seeds of tropical pioneer species under controlled and natural conditions. Revista Brasilica Botanica, v.24, n.1, p.7984, 2001. 